\title{
PELATIHAN DESAIN KEMASAN PRODUK UNTUK UMKM KERAJINAN, KULINER DAN POSDAYA
}

\author{
Mochammad Rofieq ${ }^{1)}$, Andi Poerwanto ${ }^{2)}$, Hery Budiyanto ${ }^{3)}$ \\ ${ }^{1,3)}$ Fakultas Teknik Universitas Merdeka Malang \\ ${ }^{2)}$ Fakultas Hukum Universitas Merdeka Malang
}

\begin{abstract}
ABSTRAK
Guna mewujudkan ciri khas Universitas Merdeka Malang sebagai tempat pembentukan Sarjana yang sujana dan Sarjana yang mandiri sesuai dengan Pola Ilmiah Pokok (PIP) serta merealisasikan Visi dan Misi UNMER Malang dalam hal Kemandirian dan Kewirausahaan, maka Pusat Kewirausahaan, Kemandirian dan Inkubator Lembaga Penelitian dan Pengabdian kepada Masyarakat (LPPM) mensinergikan Program Pengembangan Kewirausahaan LPPM dengan berbagai pihak, diantaranya : Usaha Mikro, Kecil dan Menengah (UMKM) Kota Malang, Program Posdaya Wilayah Jawa Timur II, Program Penelitian / Pengabdian Kemenristek Dikti serta Pemerintah Daerah melalui Dinas terkait. Sebagai salah satu bentuk sinergi, LPPM Universitas Merdeka Malang bekerjasama dengan Asosiasi Kuliner Indonesia (AKU) dan Asosiasi Perajin Kota Malang (APKM) menyelenggarakan Pelatihan Desain Kemasan Produk, guna memberikan keterampilan bagi masyarakat melalui UMKM Kerajinan, Kuliner dan Posdaya.
\end{abstract}

Kata Kunci : Desain, Kemasan Produk, Keterampilan, Posdaya,

\section{PENDAHULUAN}

Universitas Merdeka Malang adalah Perguruan Tinggi yang sangat konsisten menjadikan Kemandirian dan Kewirausahaan sebagai Pola Ilmiah Pokok dalam proses belajar mengajarnya. Hal ini juga sejalan dengan Visi Perguruan Tinggi ini : "Menjadi Pusat Pengembangan IPTEKS, Kewirausahaan dan Pengembangan Sumberdaya Manusia yang Berkualitas, Profesional, Kompetitif, Mandiri dan Berjiwa Wirausaha, Beriman dan Bertaqwa kepada Tuhan Yang Maha Esa".

Sebagai salah satu upaya guna mewujudkan ciri khas Universitas Merdeka Malang sebagai tempat pembentukan Sarjana yang sujana dan Sarjana yang mandiri sesuai dengan Pola Ilmiah Pokok tersebut, Lembaga Penelitian dan Pengabdian kepada Masyarakat (LPPM) Universitas Merdeka Malang melalui Pusat Kewirausahaan, Kemandirian dan Inkubatornya mensinergikan Program Pengembangan Kewirausahaan LPPM dengan kegiatan pengabdian masyarakat bersama Asosiasi Kuliner Indonesia (AKU) dan Asosiasi Perajin Kota Malang (APKM).

Sinergi ini dilakukan untuk menumbuhkan semangat dan rasa memiliki segenap warga civitas akademika UNMER Malang bersama stakeholder dalam menggerakkan program Kemandirian dan Kewirausahaan, salah satunya dengan menyelenggarakan Pelatihan Desain Kemasan Produk guna memberikan keterampilan bagi masyarakat melalui UMKM Kerajinan, Kuliner dan Posdaya.

\section{Inkubator Bisnis Merdeka}

Dalam melaksanakan program kerjanya, Pusat Kewirausahaan, Kemandirian dan Inkubator Lembaga Penelitian dan Pengabdian kepada Masyarakat (LPPM) Universitas Merdeka Malang memiliki satu wadah bernama Inkubator Bisnis Merdeka, yang bertugas melaksanakan kegiatan pelatihan dan pendampingan bagi mahasiswa (Tenant Inwall) dan masyarakat (Tenant Outwall).

\section{Kelembagaan Inkubator}

a. Tahun Berdiri : 2015

b. SK Pendirian : SK Rektor Universitas Merdeka Malang No: Kep. 268-A / UM / XII / 2015 tanggal : 2 Desember 2015

c. Visi : Menjadi pusat pengembangan sumberdaya manusia, yang berkualitas, profesional, kompetitif, mandiri dan berjiwa wirausaha.

d. Misi

: 1. Menyelenggarakan program inkubasi bagi tenan yang berasaldari dosen, mahasiswa dan masyarakat.

2. Menyelenggarakan kegiatan pelatihan bagi tenan yang berasaldari dosen, mahasiswa dan masyarakat. 
3. Menyelenggarakan pendampingan bagi tenan yang berasal dari dosen, mahasiswa dan masyarakat. e. Jasa Layanan Inkubator : Program Inkubasi, Program Pelatihan dan Pendampingan

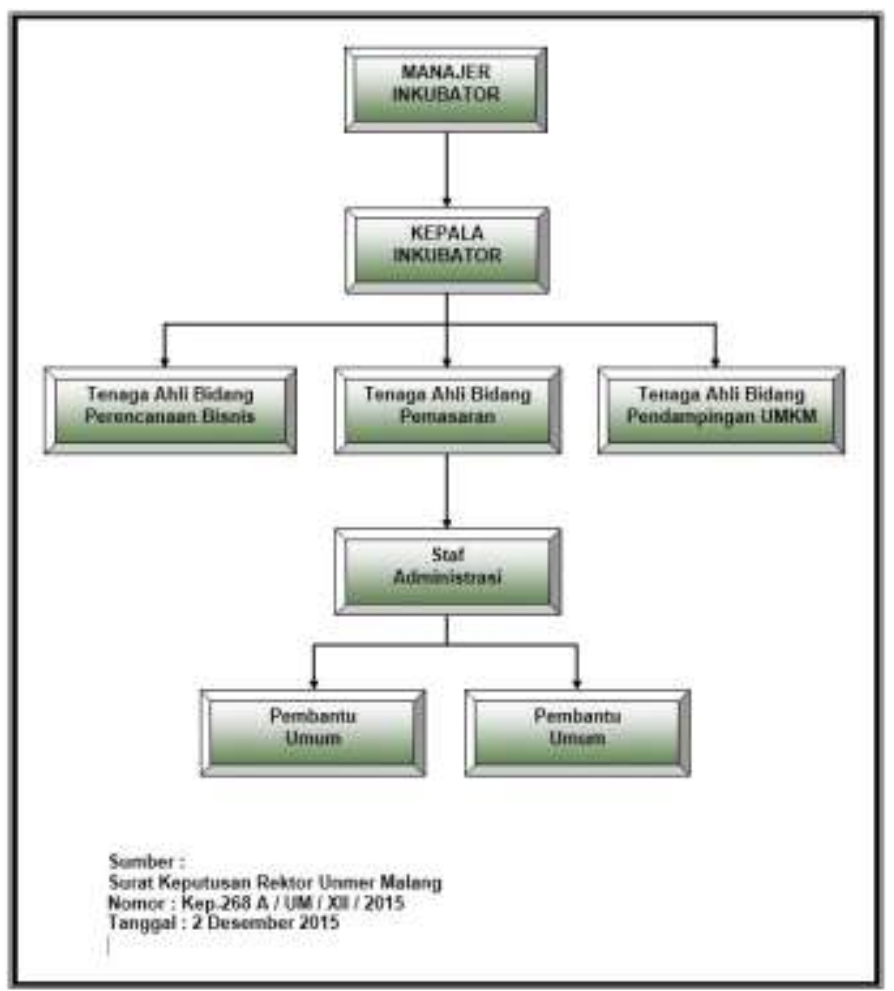

Gambar 1. Struktur Organisasi Inkubator

Tabel 1. Kriteria dan Keadaan Inkubator

\begin{tabular}{|c|c|c|}
\hline No & KRITERIA & KEADAAN INKUBATOR \\
\hline \multirow[t]{3}{*}{1} & Legalitas Inkubator Wirausaha & $\begin{array}{l}\text { SK Rektor Universitas Merdelca Malang } \\
\text { Nomor : Kep. } 268 \text { A / UM / XII / } 2015 \\
\text { Tanggal : 2 Desember 2015 }\end{array}$ \\
\hline & SUMIBERDAYA & \\
\hline & Total SDM Pengelola & 8 orang staf manajemen \\
\hline 2 & $\begin{array}{l}\text { SDM Pengelola Penuh Waktu ( } 40 \\
\text { jam keria per mingzu di inkubator) }\end{array}$ & 2 orang staf manajemen penuh waltu \\
\hline 3 & Luas Bangunan / Gedung Inkubator & $18 \mathrm{~m} \times 15 \mathrm{~m}=270 \mathrm{~m}^{2}$ \\
\hline \multirow[t]{2}{*}{4} & Luas Ruang Usaha Tenant & $\begin{array}{l}7,5 \mathrm{~m} \times 5,5 \mathrm{~m}=41,25 \mathrm{~m}^{2} \\
\text { (15\% dari luas bangunan) }\end{array}$ \\
\hline & $\begin{array}{l}\text { OPERASIONAL DAN } \\
\text { PROCRAM }\end{array}$ & \\
\hline 5 & Jumlah tenant imsall pada gaat ini & 15 orang \\
\hline \multirow[t]{2}{*}{6} & $\begin{array}{l}\text { Kemampuan memenuhi biaya } \\
\text { operasional dari dana yang } \\
\text { diciptakan inkubator sendiri (tidak } \\
\text { termasuk dana dari lembaga pendiri } \\
\text { inkubator) }\end{array}$ & $\begin{array}{l}\text { Pendapatan dari pendampingan } 9 \text { UMKM : } \\
\text { Rata-rata Rp. } 3.000 .000,-\times 9 \times 10 \% \text { x } \\
12 \text { bulan = Rp. } 32.400 .000,-/ \text { tahun. }\end{array}$ \\
\hline & $\begin{array}{l}\text { Akses terhadap peralatan dan lab } \\
\text { uii }\end{array}$ & $\begin{array}{l}\text { Di lingkungan lembaga pemilik Inkubator } \\
\text { Wiraugaha }\end{array}$ \\
\hline 7 & Jejaring & $\begin{array}{l}\text { 1. LPPM Perguruan Tinggi di Kota Malang } \\
\text { 2. Asosiasi Perajin Kota Malang } \\
\text { 3. Program Posdaya Wilayah Jawa Timur II } \\
\text { 4. Tenant Inwall dan Outwall }\end{array}$ \\
\hline
\end{tabular}




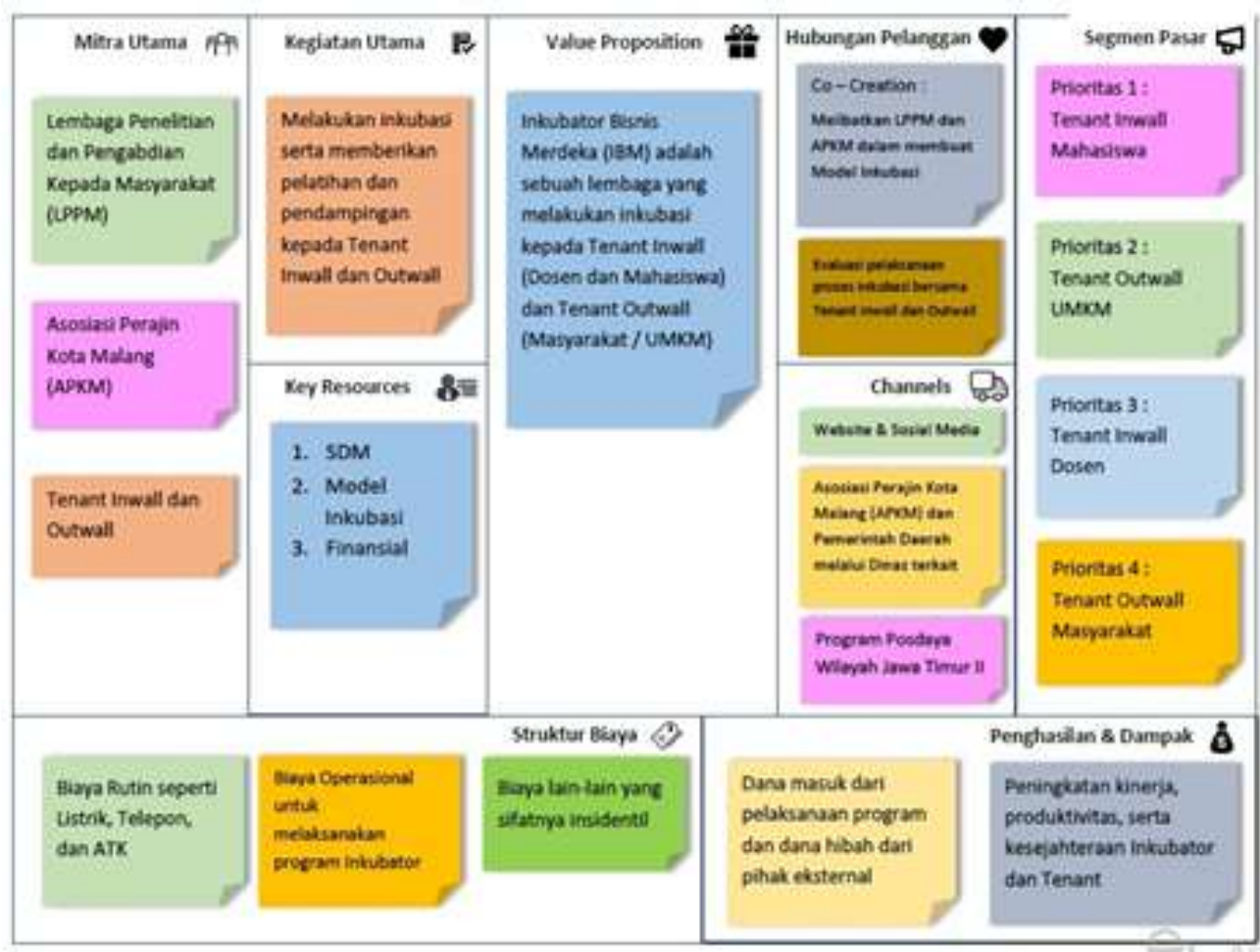

Gamar 2. Business Canvas Model Inkubator

\section{METODE KEGIATAN}

Kegiatan pengabdian kepada masyarakat yang dilaksanakan oleh Pusat Kewirausahaan, Kemandirian dan Inkubator LPPM Universitas Merdeka Malang ini diawali dengan ditandatanganinya surat kesediaan bekerjasama antara LPPM Unmer Malang dengan Asosiasi Kuliner Indonesia (AKU) dan Asosiasi Perajin Kota Malang (APKM) dalam pelaksanaan Pelatihan Desain Kemasan Produk bagi masyarakat.
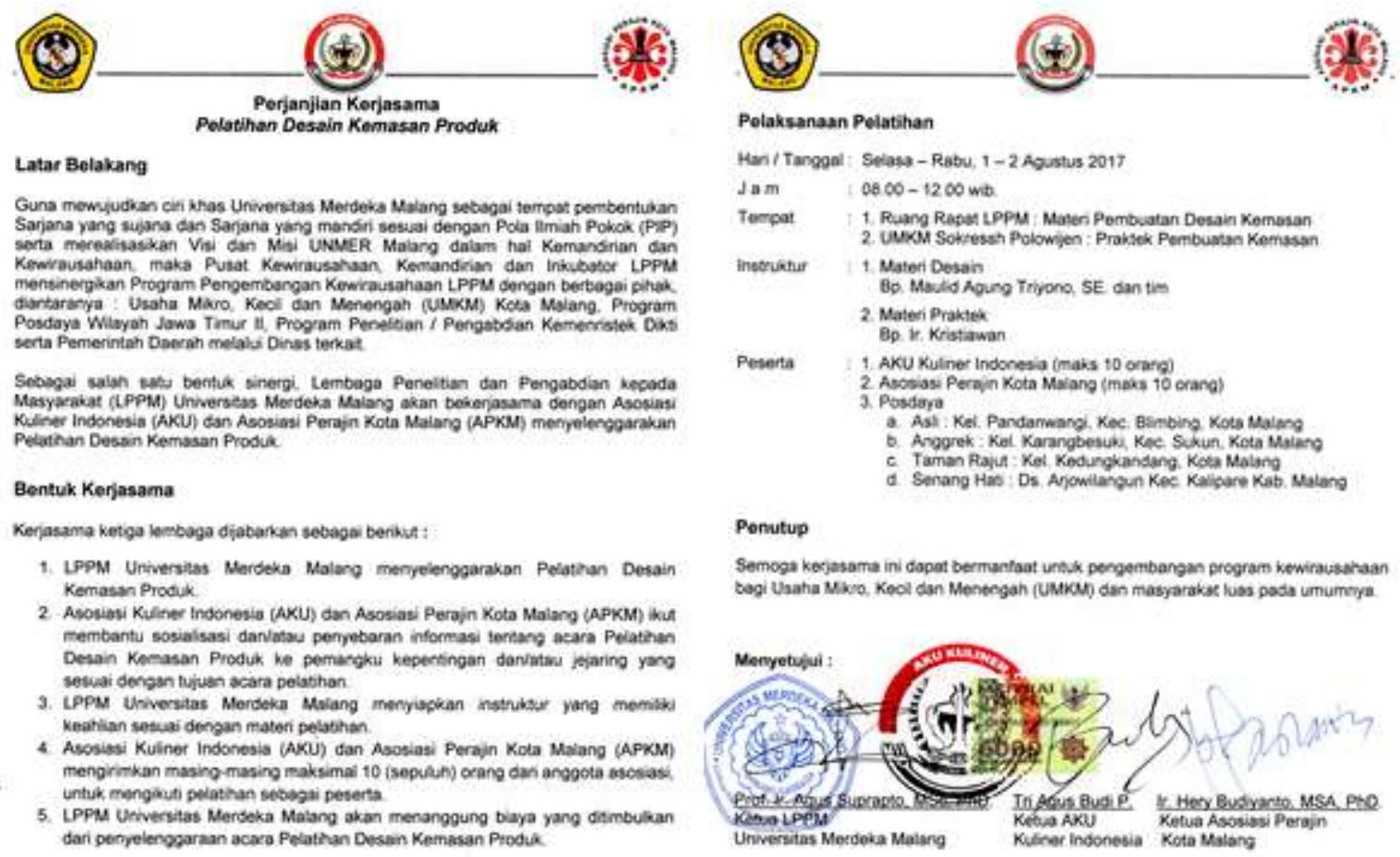

Polaksanaan Pelatihan

Han / Tanggal: Selass - Rabu, 1 - 2,Agustus 2017

$\mathrm{Iam} \quad 0800-1200$ with

Tompat it. Ruang Reser LPPM : Maten Pembuatan Desain Kemosan

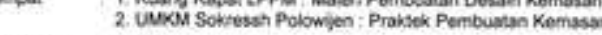

inecrivtur it Materi Desain

Bd. Mould Agung Triono, SE dan tim

2. Materi Praktex

Pesenta AKU Kulner Indonesia imaks to orare

2 Asosiss Percin Kota Malang (make 10 crang)

3. Posdaya

a. Ast : Ket. Pandarwangi, Kec, Bsimbine Kots Malusg

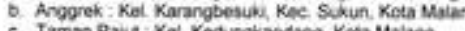

d. Senang Has : Ds Ajowilangun Kes Kalisare Kab, Matang

Ponutup

Semoga kejasama ini dopot bermurtaat unak pergembangan program kewirausahaan bagi Usaha Mivo, Keol dan Mentegah (UMicup das masyarakat luas posa umumnea.

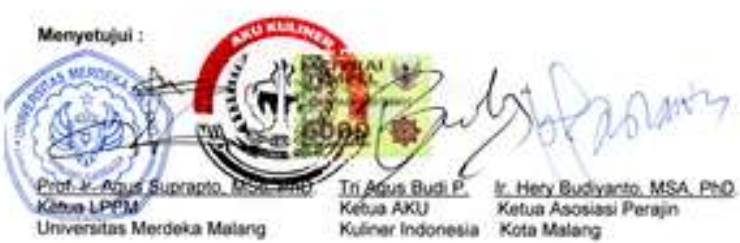

Gambar 3. Surat Perjanjian Kerjasama LPPM - AKU - APKM 
Kegiatan Pelatihan Desain Kemasan Produk yang bertujuan untuk memberikan bekal keterampilan bagi masyarakat melalui UMKM Kerajinan, Kuliner dan Posdaya ini dijabarkan sebagai berikut :

1. LPPM Universitas Merdeka Malang menyelenggarakan Pelatihan Desain Kemasan Produk.

2. Asosiasi Kuliner Indonesia (AKU) dan Asosiasi Perajin Kota Malang (APKM) ikut membantu sosialisasi dan/atau penyebaran informasi tentang acara Pelatihan Desain Kemasan Produk ke pemangku kepentingan dan/atau jejaring yang sesuai dengan tujuan acara pelatihan.

3. LPPM Universitas Merdeka Malang menyiapkan instruktur yang memiliki keahlian sesuai dengan materi pelatihan.

4. Asosiasi Kuliner Indonesia (AKU) dan Asosiasi Perajin Kota Malang (APKM) mengirimkan masing-masing maksimal 10 (sepuluh) orang dari anggota asosiasi, untuk mengikuti pelatihan sebagai peserta.

5. LPPM Universitas Merdeka Malang menanggung biaya yang ditimbulkan dari penyelenggaraan acara Pelatihan Desain Kemasan Produk.

\section{Pelaksanaan Pelatihan}

Pelatihan Desain Kemasan Produk yang dilaksanakan selama dua hari ini diikuti oleh 20 (dua puluh) orang peserta yang berasal dari LPPM Universitas Merdeka Malang, Asosiasi Kuliner Indonesia (AKU), Asosiasi Perajin Kota Malang (APKM) dan Posdaya, dengan data selengkapnya sebagai berikut :

Tabel 2. Data Peserta Pelatihan

\begin{tabular}{|c|l|l|}
\hline NO & \multicolumn{1}{|c|}{ N A M A } & \multicolumn{1}{|c|}{ KETERANGAN } \\
\hline 1 & Agus Suprapto & LPPM \\
\hline 2 & Mochammad Rofieq & LPPM \\
\hline 3 & Andi Poerwanto & LPPM \\
\hline 4 & Hery Budiyanto & GS4 Woodcraft (APKM) \\
\hline 5 & M. Iqbal Nur B.P. & GS4 Woodcraft (APKM) \\
\hline 6 & Neni Tantowi & Chayo Craft (APKM) \\
\hline 7 & Hasto Wibawanto & Bolder Korsase (APKM) \\
\hline 8 & Faishal Arifin & Silver 999 (APKM) \\
\hline 9 & Dody Triawan & Dodee La Pizza (AKU) \\
\hline 10 & Untung Samodro & Delight Foody (AKU) \\
\hline 11 & Kartika Milayanti & Missty (AKU) \\
\hline 12 & Agus Priyatno & Sosis Cinta (AKU) \\
\hline 13 & Dian Lestari & Lumpia (AKU) \\
\hline 14 & Nanik Wijayanti & Samiler Rizqi (AKU) \\
\hline 15 & Mieke Mariana & Tahu Tuna (AKU) \\
\hline 16 & Kristiawan & Kajeye Food (AKU) \\
\hline 17 & M. Zaini & Posdaya Taman Rajut \\
\hline 18 & Mudiyono & Posdaya Senang Hati \\
\hline 19 & Dyah Retno K. & Posdaya Anggrek \\
\hline 20 & Ilmiawati & Posdaya Asli \\
\hline
\end{tabular}

Pelatihan hari pertama dilaksanakan di Ruang Rapat LPPM Universitas Merdeka Malang mulai pukul 08.00 - 13.00 wib, dengan materi Pembuatan Desain Kemasan menggunakan software Corel Draw. Bertindak sebagai instruktur adalah Maulid Agung Triyono, SE., MM., Dosen dan praktisi Teknologi Informasi dari Fakultas Ekonomi dan Bisnis Universitas Merdeka Malang. Dalam pelatihan ini masing-masing peserta membawa laptop untuk mempraktekkan pembuatan desain kemasan sesuai arahan instruktur.

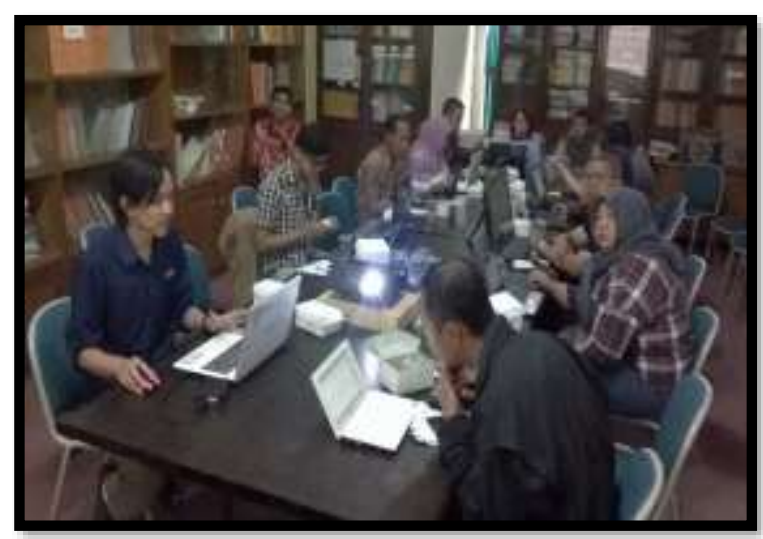

Gambar 4. Instruktur Materi Pembuatan Desain Kemasan

Pelatihan hari kedua dilaksanakan di UMKM Sokressh Kel. Polowijen Kec. Blimbing Kota Malang mulai pukul 08.00 - 15.00 wib, dengan materi Praktek Pembuatan Kemasan Produk. Bertindak sebagai instruktur adalah Ir. Kristiawan, Praktisi UMKM dan owner CV. Kajeye Food. Dalam pelatihan ini masing-masing peserta diajak mengamati proses finishing dan packaging keripik buah, serta mempraktekkan pembuatan kemasan produk sesuai arahan instruktur.

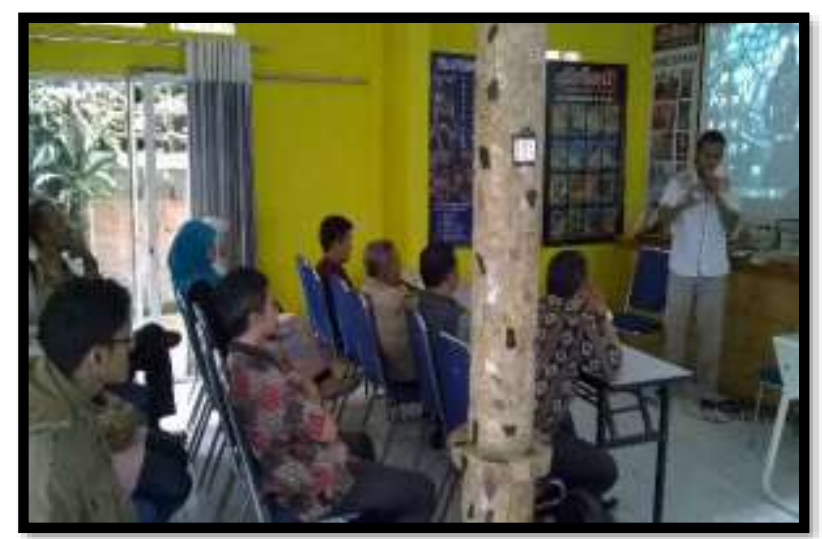

Gambar 5. Instruktur Praktek Pembuatan Kemasan Produk 


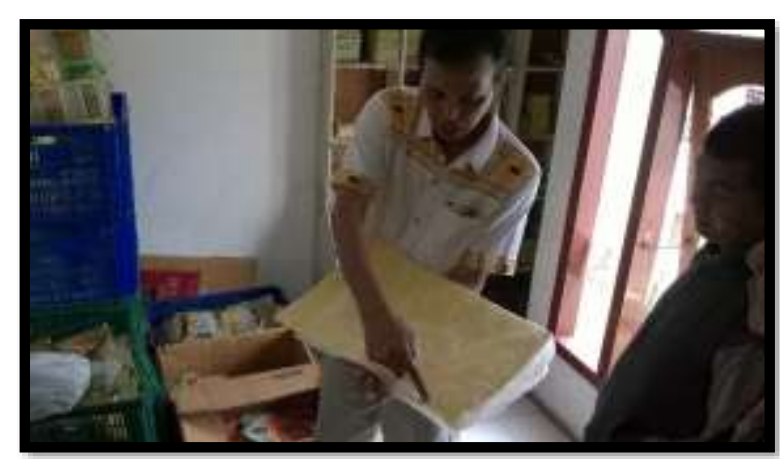

Gambar 6. Karton Bahan Kemasan Produk

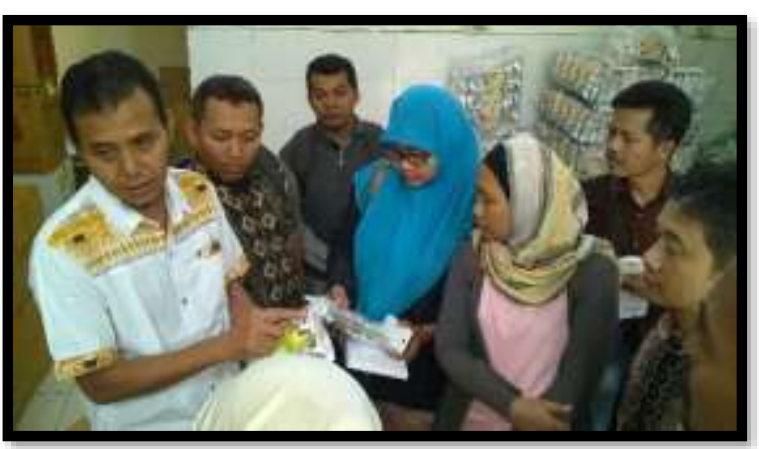

Gambar7. Kemasan Produk Cacat

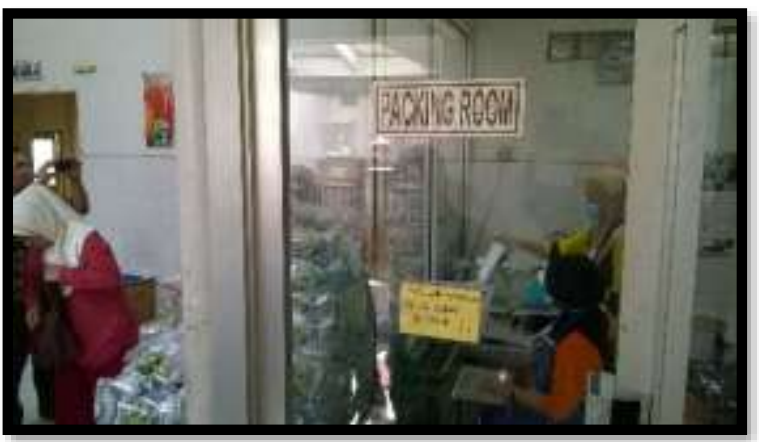

Gambar 8. Ruang Pengepakan

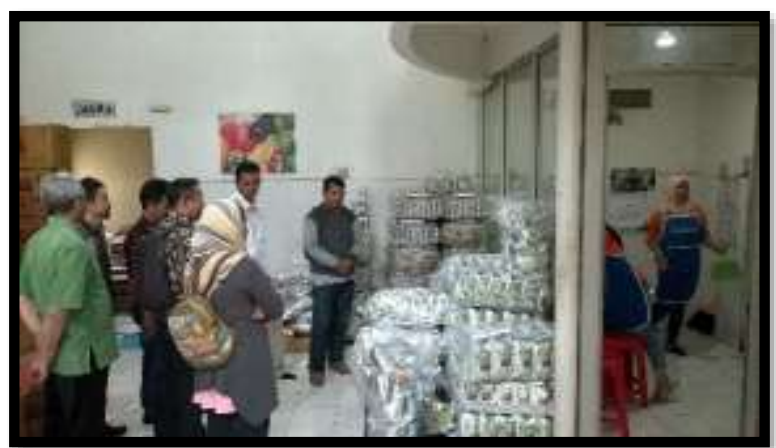

Gambar 9. Finished Good Product

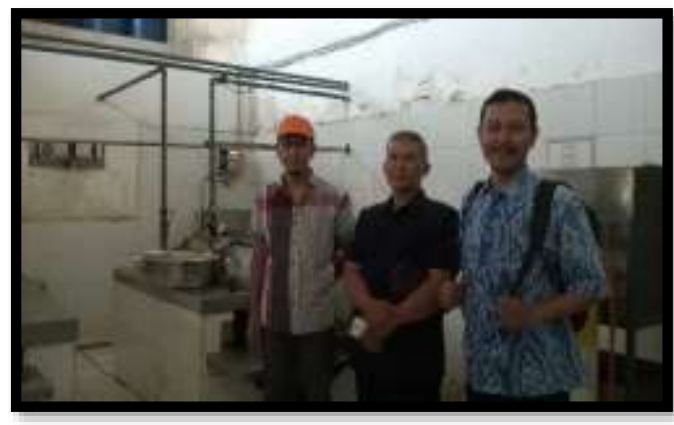

Gambar 10. Instruktur, Ketua APKM dan Ka. Pusat Kewirausahaan LPPM

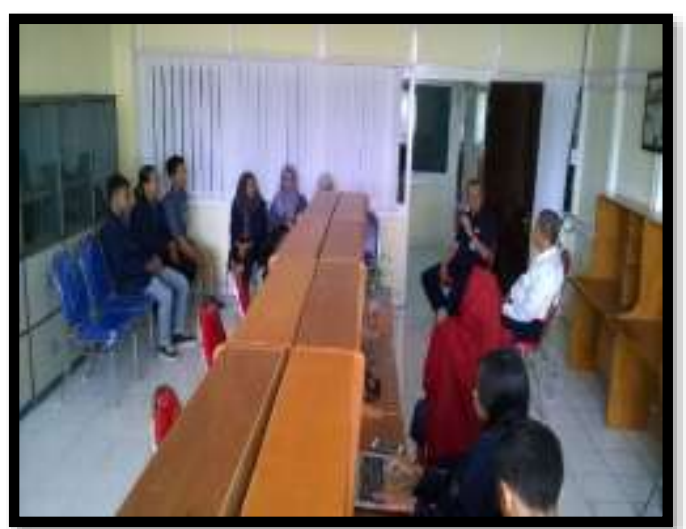

Gambar 11. Monitoring Program Kewirausahaan

\section{HASIL DAN PEMBAHASAN}

Pelatihan desain kemasan produk yang dilakukan ini sangat bermanfaat dan berdampak positif bagi masyarakat, dalam hal ini Usaha Mikro, Kecil dan Menengah (UMKM) bidang kerajinan, kuliner dan keluarga yang tergabung dalam kelompok Posdaya. Peserta pelatihan sangat antusias mengikuti tahapan demi tahapan pelatihan yang diberikan oleh instruktur yang memiliki kompetensi di bidang tersebut.

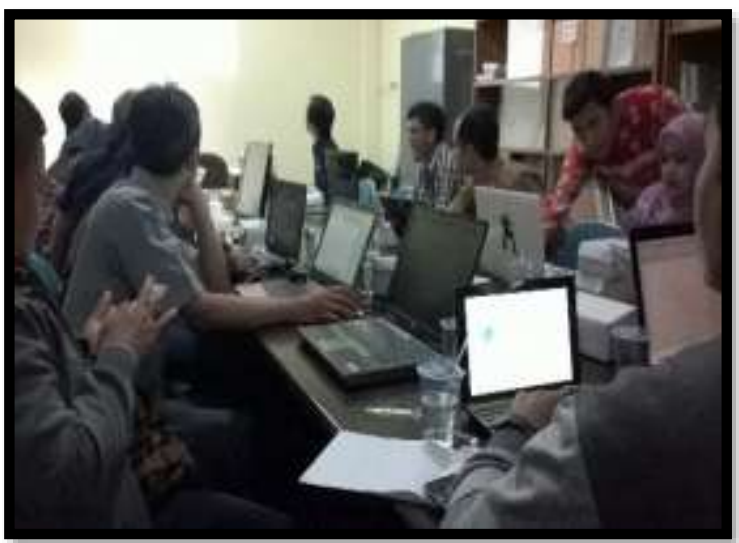

Gambar 12. Peserta Pelatihan Pembuatan Desain Kemasan Hari Pertama 


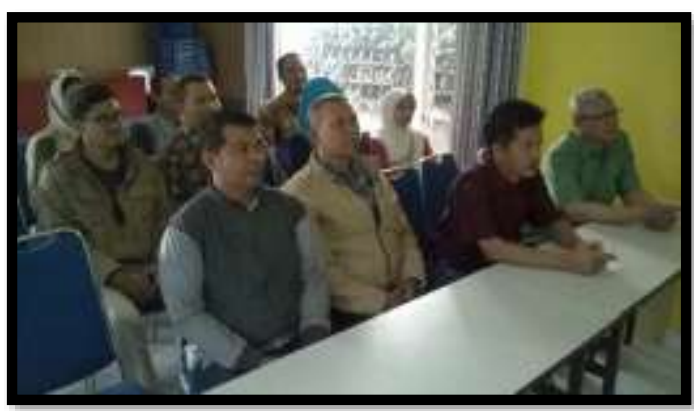

Gambar 13. Peserta Praktek Pembuatan Kemasan Produk Hari Kedua

Bagi UMKM bidang kerajinan dan kuliner, manfaat pelatihan sangat terasa karena para pelaku usaha di bidang ini dapat membuat berbagai alternatif desain untuk kemasan produknya, sehingga tampilan produknya lebih variatif, menarik (eye catching), namun masih tetap terjaga kualitas produknya. Sedangkan bagi kelompok Posdaya, pelatihan ini dapat menjadi inspirasi dan motivasi dalam memanfaatkan segala potensi yang ada di lingkungan sekitarnya.

\section{KESIMPULAN DAN SARAN}

\section{a. Kesimpulan}

Sinergi kerjasama antara Lembaga Penelitian dan Pengabdian kepada Masyarakat (LPPM) Universitas Merdeka Malang dengan Asosiasi Kuliner Indonesia (AKU), Asosiasi Perajin Kota Malang (APKM) dan Pos Pemberdayaan Keluarga (Posdaya) dalam pelaksanaan pelatihan desain kemasan produk telah memberikan dampak yang positif, karena dalam kegiatan ini Akademisi Perguruan Tinggi dan Praktisi UMKM dapat berinteraksi dalam memberikan tambahan ilmu desain dan keterampilan bagi masyarakat.

\section{b. Saran}

Sinergi dari berbagai komponen masyarakat seperti ini hendaknya dapat dilanjutkan dalam bentuk pelatihan-pelatihan yang lain, karena melalui kerjasama ini Perguruan Tinggi turut aktif mengembangkan program kewirausahaan bagi Usaha Mikro, Kecil dan Menengah (UMKM) dan masyarakat luas pada umumnya.

\section{REFERENSI}

1. Budiyanto, H., Rofieq, M. (2016). Menumbuhkembangkan Wirausaha Mahasiswa dan Alumni Melalui Program Ipteks bagi Kewirausahaan di Universitas Merdeka Malang. Jurnal ABDIMAS Volume 1 Nomor 1 Desember 2016, LPPM Universitas Merdeka Malang.

2. Rofieq, M., Sugianto, Suprapto, A. (2013). Perancangan Stasiun Kerja yang Ergonomis Guna Meningkatkan Produktivitas Pembuatan Souvenir Berbahan Limbah Lampu TL. Prosiding Seminar Nasional Manajemen Teknologi XIX, ITS Surabaya.

3. Rofieq, M., Hariyanto, S., Wiati, N.M. (2014). Penerapan Metode Kansei Engineering guna Mengidentifikasi Atribut Desain dalam Perancangan Souvenir Khas Malang. Prosiding Simposium Rekayasa Aplikasi Perancangan dan Industri RAPI XIII, Univ. Muhammadiyah Surakarta.

4. Rofieq, M., Suprapto, A., Prilaswanti, D. (2015). IbM Usaha Kerajinan Perhiasan Perak Guna Menumbuhkan Minat Berwirausaha Bagi Karang Taruna Kelurahan Tanjungrejo. Prosiding Seminar Nasional Manajemen Teknologi XXIII, ITS Surabaya.

5. Ulrich, Karl T., Eppinger, Steven D. (2001). Perancangan \& Pengembangan Produk. Penerbit Salemba Teknika, Jakarta. 